Scientiae Educatia: Jurnal Pendidikan Sains (2020), Vol 9(1): 1-13

DOI: http://dx.doi.org/10.24235/sc.educatia.v9i1.5654

Published by Tadris Biologi, IAIN Syekh Nurjati Cirebon, Indonesia. p-ISSN: 2303-1530, e-ISSN: 2527-7596

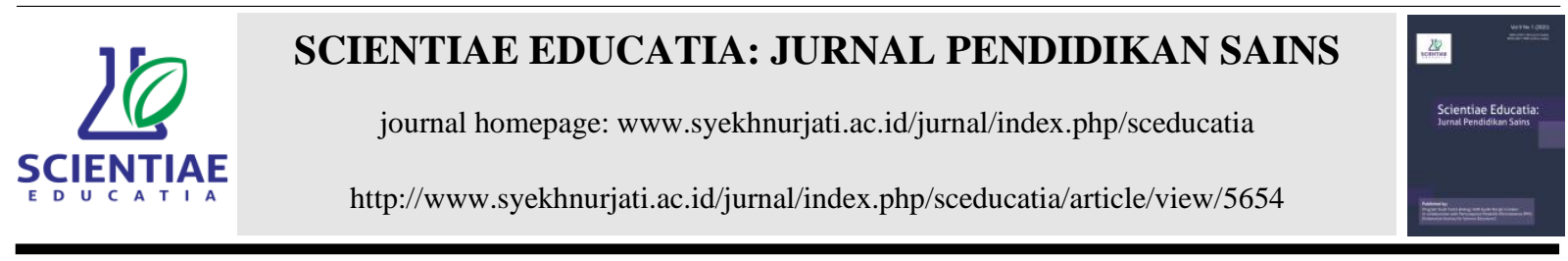

\title{
Developing an Instrument of Performance Assessment to Measure Problem- Solving Skills of Senior High School Students in Physics Inquiry-Based Learning
}

\begin{abstract}
Alda Novita Sari ${ }^{\mathrm{a}^{*}}$, Undang Rosidin $^{\mathrm{b}}$, Abdurrahman $^{\mathrm{c}}$

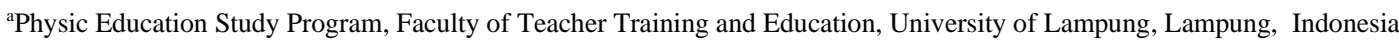
${ }^{b}$ Physic Education Study Program, Faculty of Teacher Training and Education, University of Lampung, Lampung, Indonesia 'Physic Education Study Program, Faculty of Teacher Training and Education, University of Lampung, Lampung, Indonesia

${ }^{*}$ Corresponding author: J1. Punai Jaya, Kotabumi, Tanjung Harapan, Lampung Utara, Lampung, 34517, Indonesia. E-mail addresses: aldanovitas07@gmail.com

\section{a r t i c l e i n f o}

Article history:

Received: 13 December 2019

Received in revised form: 25

December 2019

Accepted: 05 May 2020

Available online: 30 June 2020

Keywords:

Inquiry-based learning

Performance assessment

Physics

Problem-solving skill

\section{a b s t r a c t}

The assessment of students' learning results has not been fully implemented. Whereas, the importance of assessing students is to find out the development of learning abilities in solving problems, but many obstacles are still faced by educators at SMAN (high school) 5, SMAN (high school)15, and SMAN (high school) 16 Bandar Lampung. This study aims to produce a valid product and determine the feasibility of construction, substance, and language. Sugiyono's research design development model was divided into (1) potential and problem, (2) data collection, (3) product design, (4) design validation, (5) design revision. The product is valid because the expert validator accepts the instrument in terms of both content and format, including instrument outline, learning scenario, rubric, and scoring guideline. The construction aspect score was 3.59 while the substance aspect score was 3.56 , and the language aspect score was 3.58. The validation test result meets very sufficient quality criteria. Therefore, the product performance assessment instrument to measure problem-solving skills in physics inquiry-based learning of senior high school students can be used.
\end{abstract}

\section{Introduction}

21 st Century or the globalization era is an era with many changes covering several fields such as science, technology, and education. Regarding the change of education paradigm in the 21st century, (BSNP, 2010) in the "21st Century Partnership Learning Framework," there are competencies and expertise that must be possessed by Human Resources, one of them is problem-solving Skills. The choice of physics learning models is very influential in the process of students' problem-solving to be successful. Solving problems requires freedom of thinking about and finding conclusions (Uus, 2017). The general strategy in solving problems consists of 5 steps which are identification, representation, strategy, implementation, and evaluation (Patnani, 2013). Meanwhile, according to (Rostika \& Junita, 2017), the problemsolving stages are understanding, compiling, implementing, and re-examining the results. The problem-based learning stage started from orienting, organizing, guiding, presenting, and evaluating (Yusi, 2016). An alternative to this problem is the inquiry learning model. 
Based on the definition of (Aisyah \& Wasis, 2015), the inquiry in learning is an activity carried out by students. According to (Puspita \& Jatmiko, 2013), through the implementation of inquiry, students are expected to actively solve problems, then they can find answers from teachers. Problem-solving is an individual effort using knowledge and skills to find solutions from a new problem or situation that has not been known yet (Farisa et al., 2017). Physics can be delivered directly through laboratory work and demonstrations (Ihsany \& Margono, 2017). A practicum is interpreted as a learning method that functions to clarify concepts and improve students' intellectual skills (Yeni, 2017). The preliminary research in SMAN 5, SMAN 15, and SMAN 16 Bandar Lampung on six teachers and 99 students, shows that $83 \%$ of teachers used physics material applied in the student practicums, but none of them measured problemsolving skills.

The inquiry in practical activities carried out by students must be assessed by teachers (Amelia, 2015). Assessment makes it easy for teachers in the learning process to measure students' all competencies (Safitri et al., 2017). Knowledge, ability, and experience needed in solving problems are necessary to be built in the stages of building students' knowledge base (Putri \& Sutarno, 2012). In line with the opinions above, Suprananto and Kusaeri (2012) explain that assessment of a systematic process includes the activity of collecting, analyzing, and interpreting information to determine the characteristics of students in achieving the learning objectives. Learning must take the form of interactions between teachers and students so that they can harmonize the integrated activities (Sundari, 2014).

Students' learning results during the practicum will be observed if teachers conduct an inquiry-based performance assessment on students' practicum activities. Performance assessment is very suitable to assess the competency achievement that requires students to perform certain tasks, such as practice in the laboratory (Rosidin, 2016). Toheri and Yeni (2014) also explain that the performance assessment is the result of observing student activities as they occur. Psychomotor aspects show the ability, especially the level of laboratory inquiry classified as skilled in conducting practicum (Sulistiawan et al., 2017). According to Wenning (2011), the inquiry lab has a role in encouraging students actively to be involved in learning activities, such as observation, opinion, generalization, verification, result, and conclusion.

Inquiry learning is a series of activities emphasizing analytical processes to find answers from problems that are questioned (Laksana \& Dasna, 2017). As explained by Saiful (2017), 
the inquiry emphasizes more on student learning activities. Students can develop the skill aspect by formulating questions. The facts prove that there are no teachers from these schools having assessed all aspects, but each aspect is supposed to be assessed based on certain percentages $53 \%$ affective, $17 \%$ psychomotor, and 30\% subjective. Performance assessment is an alternative that provides an assessment of a process to raise skills, attitudes, and products (Dewi \& Rosana, 2017).

One important component of performance assessment is the scoring plan, including rubrics. The rubric is an assessment guide describing the teachers' criteria in assessing the level of students' work (Widya \& Novianti, 2016). The analytic rubric requires the teacher to produce several scores at the beginning, then followed by the total final assessment score. The holistic rubric that will be used in this product requires the teachers to assess and give a score on the performance of students for once (Mertler, 2001).

Performance appraisal can make students perform during practical work and improve their abilities (Eka, 2015). 83\% of teachers used assessment tools to assess. However, the effort to assess students' performance was considered very low, as only $21 \%$ of physics teachers assessed students' performance while observing them around during the practicum process. The limited number of assessments done by the teachers affects the ability of students to perform their practicums. Thus, the relevant assessment and its instruments are urgently needed. All physics teachers of these schools had difficulty in making and evaluating through performance assessment instruments.

The results of the distribution of needs analysis questionnaire to 6 teachers and 99 students in SMAN 5, SMAN 15, and SMAN 16 Bandar Lampung, show that $100 \%$ of teachers and 93\% of students agree with the necessity to develop inquiry-based performance assessment instruments in practicum activities to measure problem-solving. This study aims to create a valid development product and determine the feasibility of construction, substance, language in instrument performance assessment to measure problem-solving skills in physics inquirybased learning of Senior High School students. The significance of implementing an instrument of the performance assessment product development can be used as a guide to evaluating the psychomotor aspects of students during the practicum process. This instrument can also be used as a reference for making other performance assessment instruments. 


\section{Method}

This research was conducted to develop a valid performance assessment instrument to measure problem-solving skills in physics inquiry-based learning of Senior High School students. This development used the methods included in the research and development. These development research methods were used to produce a product and to validate it in terms of the appropriateness of content, construction, and language to be useful for teachers in assessing students. The research subject in this development was the instrument performance assessment measuring problem-solving skills in physics inquiry-based learning. The experts testing this subject were the lecturers of Faculty of Teacher Training and Education, University of Lampung. At the data collection stage, the data was obtained from the questionnaire filled out by the teachers and students regarding the availability of learning assessment tools. The instruments used in this study were the needs analysis questionnaire, construction validation questionnaire, substance validation, and language validation test questionnaire.

The research design refers to Sugiyono (2018) in terms of the development research in which the stage is a cycle that includes a study of various findings in the field related to the product to which will be created but it is limited to the design revision stage adjusting the needs accordingly.

The product development procedure is shown in Figure 1.

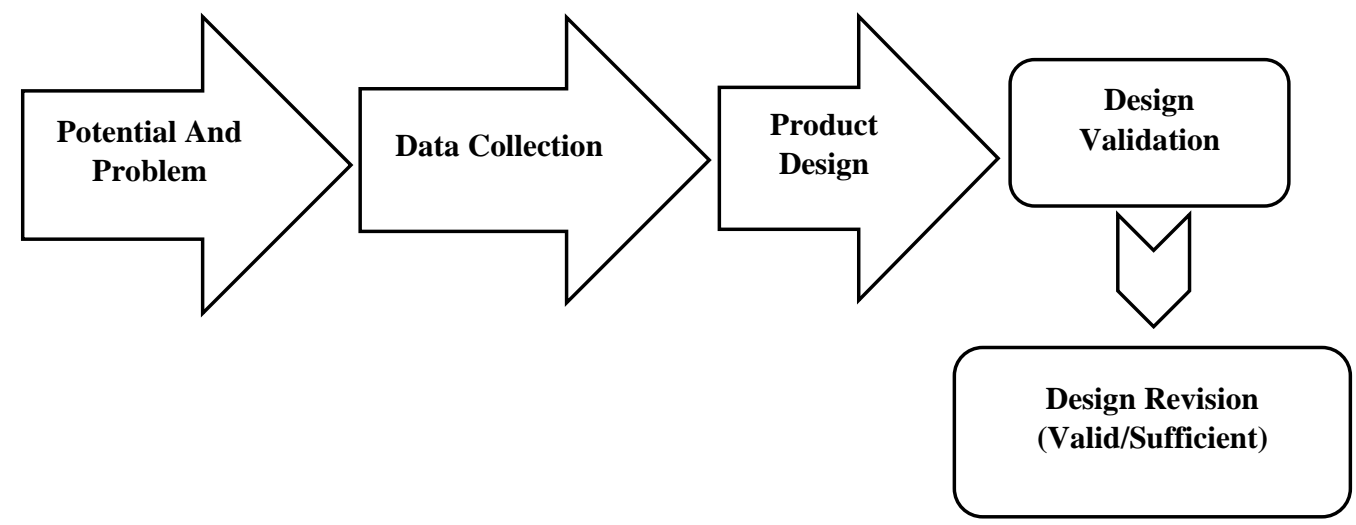

Figure 1. Research and Development (R\&D) Method Referring to Research Design (Sugiyono, 2018)

Based on the data obtained from the results of the expert validation, the feasibility will be determined according to the scores shown in Table 1. 
Table 1. Converting Rating Score into Quality Score Statement

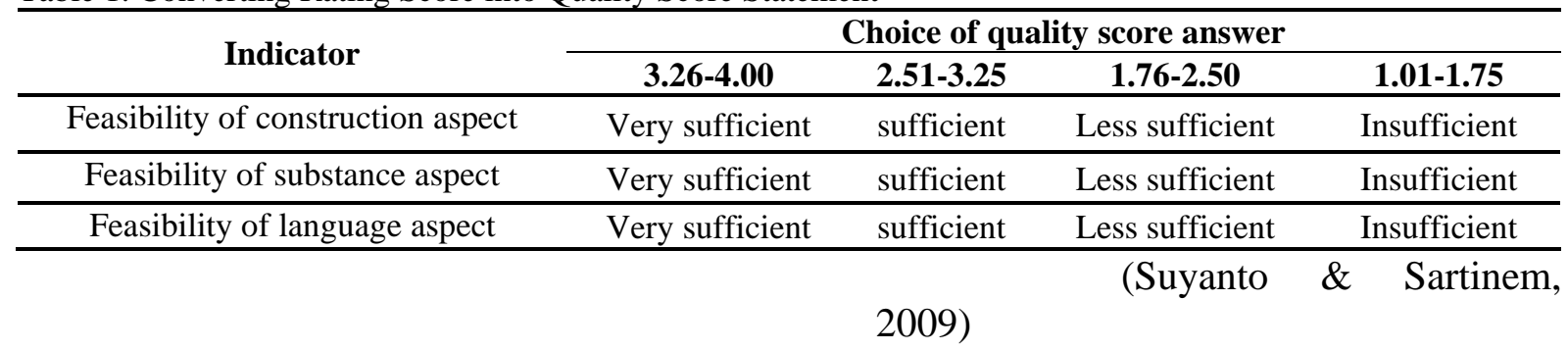

Quality statements are used to determine the feasibility of the product being developed. The quality obtained determines the researcher in following up the product. The researchers determined the scale and rubric of the performance assessment, as described in Table 2.

Table 2. Scale and Instrument Rubric

\begin{tabular}{|c|c|}
\hline Scale & Rubric \\
\hline 0 & Does not show any understanding of the problem. \\
\hline 1 & $\begin{array}{c}\text { Shows a limited understanding of the problem. Many task requirements are not visible in the } \\
\text { response. }\end{array}$ \\
\hline 2 & $\begin{array}{c}\text { Shows a partial understanding of its understanding. Most task requirements are included in the } \\
\text { response. }\end{array}$ \\
\hline 3 & $\begin{array}{c}\text { Demonstrates a sufficient understanding of the problem. All task requirements are included in the } \\
\text { response. }\end{array}$ \\
\hline 4 & $\begin{array}{c}\text { Shows a complete understanding of the problem. All task requirements are included in the } \\
\text { response. }\end{array}$ \\
\hline
\end{tabular}

This product is equipped with a scoring guideline to decide the quality of students, as shown in Table 3.

Table 3. Criteria for Rating Quality Letters

\begin{tabular}{cc}
\hline Final Score & Quality \\
\hline$>75$ & Very Good (A) \\
$66-75$ & Good (B) \\
$56-65$ & Sufficient (C) \\
$50-55$ & Insufficient (D) \\
$<50$ & Very Insufficient (E) \\
\hline
\end{tabular}

\section{Result and Discussion}

This development research produced a product in the form of a performance assessment instrument to measure problem-solving skills in of Senior High School students in physics inquiry-based learning. The stages of the development procedure are: 1) potential and problem, 2) information and data collection, 3) product design, 4) design validation, 5) design revision. Based on the analysis of 99 students and six physics teachers at SMAN 5, SMAN 15, and SMAN 16 Bandar Lampung, researchers found potentials and problems in this study as described in Table 4.Table 4. Potential and Problem 


\begin{tabular}{cc}
\hline Potential & Problem \\
\hline $\begin{array}{c}\text { In the practicum process, there were } \\
92 \% \text { of students showed good } \\
\text { performance. }\end{array}$ & $\begin{array}{c}\text { The teachers evaluating the psychomotor aspects in the practicum } \\
\text { process was only 17\%, which was still relatively low in assessing } \\
\text { students' performance. }\end{array}$ \\
$\begin{array}{c}\text { 86\% of teachers gave the topic of } \\
\text { physics problems for students to be } \\
\text { solved. }\end{array}$ & $\begin{array}{c}\text { In subjective assessment, there are } 50 \% \text { of teachers assigned to } \\
\text { determine students' performance. }\end{array}$ \\
$\begin{array}{c}\text { There were 92\% of teachers assessing } \\
\text { students' practicum processes. }\end{array}$ & $100 \%$ of the teachers find it difficult in making performance \\
\end{tabular}

Similarly, Ariani (2016) emphasizes the importance of identifying the potential and problems to measure the achievement of students' learning results. Teachers' feedback is needed to improve the learning process. Based on the assessment of potential and problems, students can obtain information about their weaknesses and strengths. However, many teachers do not conduct a comprehensive assessment yet. Therefore, the researchers developed an instrument of the performance assessment to measure the problem-solving skills of senior high school students in physics inquiry-based learning. In short, this instrument can be used to facilitate the process of assessing students.

Information and data collection were obtained from questionnaire analysis of teachers' and students' needs, literature review from several books, and journals, in Table 5.

Table 5. Information and Data

\begin{tabular}{cc}
\hline Information & Data \\
\hline $\begin{array}{c}\text { Assessment can provide an overview of the level of } \\
\text { student' success (Uno \& Koni, 2012). }\end{array}$ & $\begin{array}{c}\text { The physics teachers develop a performance } \\
\text { appraisal device which is approved by 93\% of } \\
\text { students. }\end{array}$ \\
$\begin{array}{c}\text { Performance assessment is very suitable to assess the } \\
\text { achievement of students' competencies, such as } \\
\text { laboratory practice (Rosidin, 2016). }\end{array}$ & $\begin{array}{c}\text { 89\% of students agreed on the work assessment } \\
\text { device which is implemented by the teachers }\end{array}$ \\
$\begin{array}{c}\text { Inquiry-based learning emphasizes active students to } \\
\text { grow their ability to solve problems (Saiful, 2017). }\end{array}$ & $\begin{array}{c}\text { It was found that 100\% of teachers agreed that a } \\
\text { performance assessment instrument needs to be } \\
\text { developed. }\end{array}$ \\
\hline
\end{tabular}

At the stage of product design, the researcher analyzes the content that would be applied in the product development presented in Table 6 . 
Table 6. Content Analysis

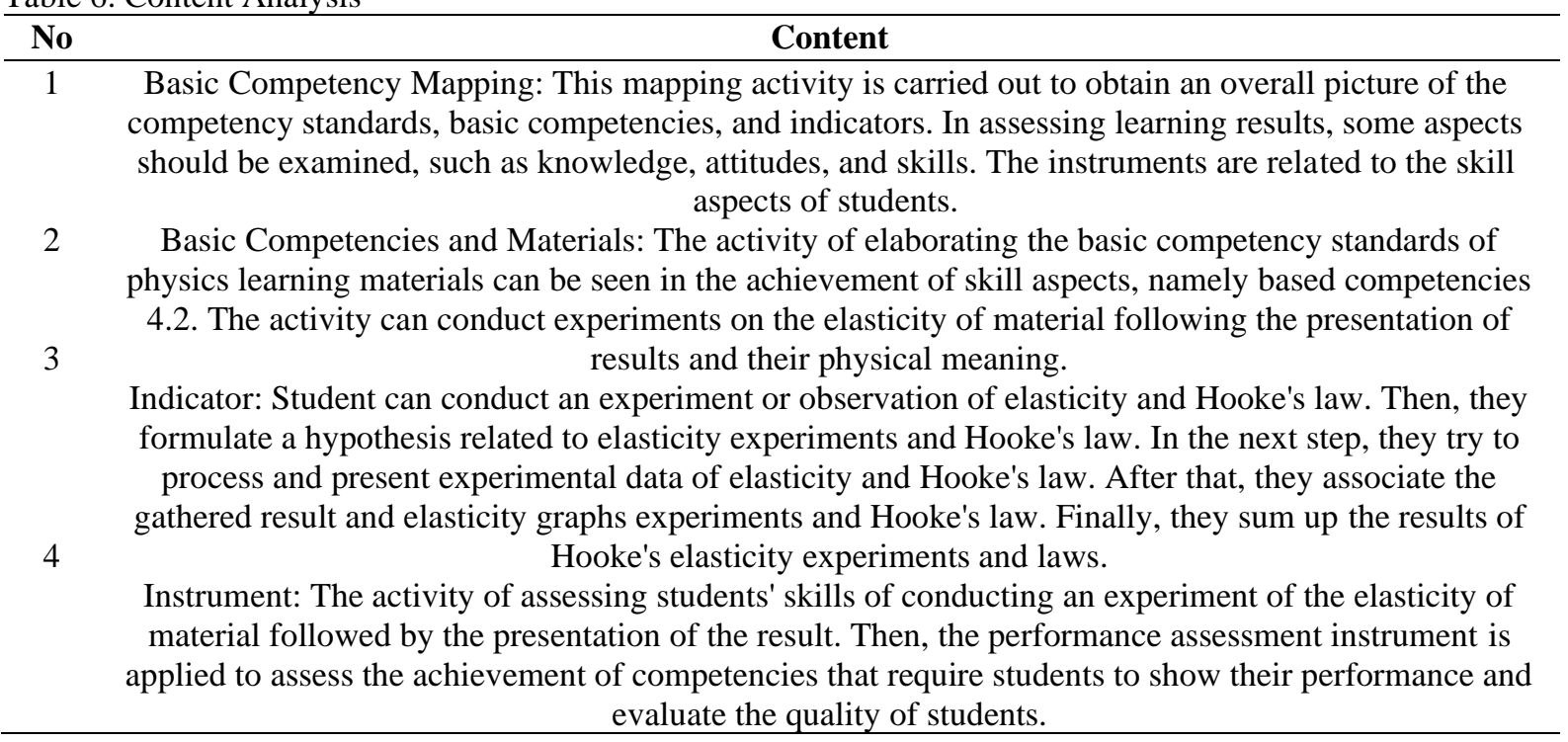

The instrument of the performance assessment applies an outlined questionnaire containing the indicators to be observed during the learning process, in Table 7.

Table 7. Product Grid

\begin{tabular}{ccccc}
\hline $\begin{array}{c}\text { Classification } \\
\text { of inquiry } \\
\text { activities }\end{array}$ & Rated aspect & $\begin{array}{c}\text { Problem-solving } \\
\text { indicator outline }\end{array}$ & Problem-solving indicator & $\begin{array}{c}\text { Psychomotor } \\
\text { Bloom taxonomy }\end{array}$ \\
\hline $\begin{array}{c}\text { Observations, } \\
\text { Opinions, }\end{array}$ & $\begin{array}{c}\text { Preparation, } \\
\text { Implementation, }\end{array}$ & $\begin{array}{c}\text { Identifying, } \\
\text { Developing a Plan, } \\
\text { Implementing a }\end{array}$ & $\begin{array}{c}\text { Observing, Taking notes, } \\
\text { Making formulation of } \\
\text { problems, Revealing ideas, }\end{array}$ & $\begin{array}{c}\text { Imitation, } \\
\text { Manipulation, } \\
\text { Precision, }\end{array}$ \\
Veneralizations & Reporting. & Plan, Explaining & $\begin{array}{c}\text { Hypothesizing, Writing out } \\
\text { results, Drawing graphics, } \\
\text { the results. }\end{array}$ & $\begin{array}{c}\text { Articulation, } \\
\text { Naturalization. }\end{array}$ \\
Conclusions, & & & $\begin{array}{c}\text { Analyzing, Making } \\
\text { conclusions. }\end{array}$ & \\
\hline
\end{tabular}

The researcher compiles the results of the learning scenario and the task of the instrument performance assessment, in Table 8 .

Table 8. Learning Scenarios and Performance Tasks

$\begin{array}{ll}\text { Learning scenarios } & \text { Performance task }\end{array}$

\begin{tabular}{cc}
\hline $\begin{array}{c}\text { The learning process consists of core } \\
\text { competencies, basic competencies, indicators of } \\
\text { competency achievement, learning objectives, } \\
\text { materials, methods, media. }\end{array}$ & $\begin{array}{c}\text { The task includes the process of observing, recording } \\
\text { various facts, and making problem statements. }\end{array}$ \\
$\begin{array}{c}\text { The learning steps are preliminary activities, core } \\
\text { activities (the process of observing, asking, } \\
\text { trying, associating, communicating), and closing } \\
\text { activities. }\end{array}$ & $\begin{array}{c}\text { The task includes the activities of checking the } \\
\text { completeness of the material tools, hypothesizing, } \\
\text { arranging experimental tools, measuring and writing the } \\
\text { results, organizing the tools, group participation, } \\
\text { analyzing data, making conclusions, and } \\
\text { communicating the results in practical activities. }\end{array}$ \\
\hline
\end{tabular}

Validation of this development is a review of the product that has been made as explained is in Table 9. 
Table 9. Validation of Instrument Product Design

\begin{tabular}{cc}
$\begin{array}{c}\text { Validated } \\
\text { aspect }\end{array}$ & Description of validated aspects \\
\hline $\begin{array}{c}\text { Construction } \\
\text { Substance }\end{array}$ & $\begin{array}{r}\text { Clarity of instructions, completeness of ideas in instructions for using instruments, selection } \\
\text { of indicators, clarity of scoring guidelines, and clarity of rubrics. } \\
\text { aspects with the indicators on the grid, the suitability of the rating scale used, and the rubric } \\
\text { suitability (scoring guidelines). }\end{array}$ \\
Language & $\begin{array}{c}\text { Communication of the language used, the use of Indonesian, completeness of ideas in } \\
\text { sentences, use of the number of words in sentences, and the sentences are independent of the } \\
\text { provided statements. }\end{array}$ \\
\hline
\end{tabular}

Design validation is tested by the four validators to obtain scores in Figure 2.

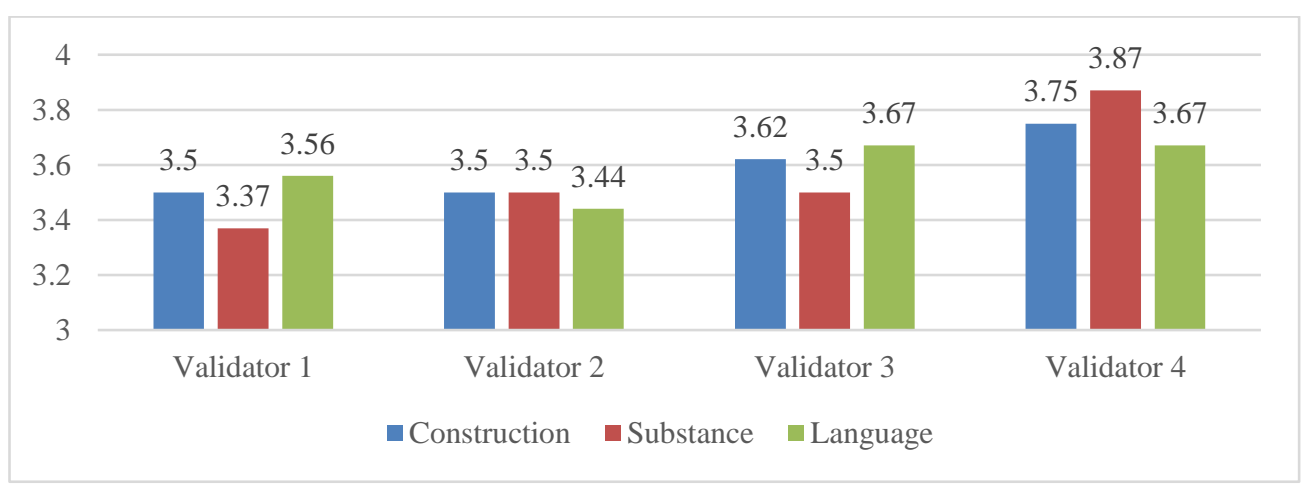

Figure 2. Instrument Product Design Validation Score

The validators gave the average scores on the aspects of construction, substance, and language presented in Figure 3.

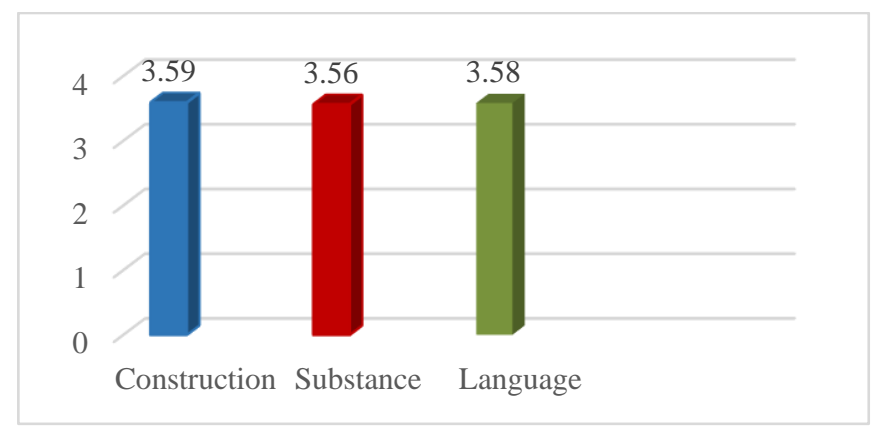

Figure 3. Average Results of Construction, Substance, and Language Validator Scores

The product development improvement results are called prototypes. The validation test process took place in the Faculty of Teacher Traning and Education, University of Lampung, and SMA Muhammadiyah 2 SMA Bandar Lampung from 2 to 21 September 2019. The product validators are two lecturers of the Faculty of Teacher Traning and Education, University of Lampung, one teacher of SMA Muhammadiyah 2 Bandar Lampung, and one teacher of SMAN 1 Banjar Agung and the experts as well as linguists. The results of the 
prototype product developed to measure the inquiry-based problem-solving skills based on the set indicators of the intended activities of the students, such as observing, taking notes, formulating problems, expressing ideas, hypothesizing, writing results, drawing graphs, analyzing, making conclusions. The overall improvements suggested by the four validators encompass several aspects as elaborated further in Table 10.

Table 10. Instrument Product Design Revision

\begin{tabular}{ll}
\hline Product components & \multicolumn{1}{c}{ Criticism and suggestions } \\
\hline Instrument Grid & Add instrument lines to reporting aspects. \\
Learning Scenarios & It was improving learning objectives by using the ABCD component, namely \\
and Task Performance & Participants (learners), Behavior (observed behaviour), Condition (requirements that \\
& need to be fulfilled), Degree (a measure of achieving goals). \\
& It is adding preliminary activities in several phenomena as well as interesting videos \\
that are closely related to real life. Thus, students' learning interest can increase. & You were making your own graphic images on the material to describe better about \\
& the force applied to the additional extension of the metal. \\
& They are erasing the massive data from tables that do not need to be filled. So, \\
& students fill in according to the process of the practicum activity. \\
& They are repeating the experiment at least three times. Thus, the time allocation of \\
& practical learning is more effective, and the assessment objectives are met. \\
& Replacing photos sourced from the internet with their photos taken from the tools \\
& and materials of the Physics Education laboratory of Faculty of Teacher Training and \\
& Education, University of Lampung \\
& Changing the series of experiments by using springs. Please be advised if schools do \\
& not have these devices, just use wire. \\
& Adding references to the material elasticity and Hooke's law. \\
& They are improving authorship in accordance with improved spelling provisions. \\
& Writing taxonomic numbering on the instrument. \\
Making measurable items of the instruments & Adding all subject captions to the grading rubric. \\
Scales, Rubrics and & \\
Scoring Guidelines &
\end{tabular}

The instrument performance was revised several times as adjusted to the critics and suggestions given by the validators. As according to Fraenkel et al. (2012), instrument is declared valid depends on the expert. The expert was free to assess whether or not this instrument was valid. The indicator of a valid instrument is that the experts accept the instrument regarding both its content and format without any improvement. If the expert still asked for a revision, the revision still needs to be done until the experts accept the instrument unconditionally.

Based on the results of the validation as well as the experts' opinion, it was concluded that the developed product was valid since the instrument of the performance assessment that was tested by the four expert validators had been approved in terms of contents and formats. This approval included the instrument outline, learning scenarios, rubrics, and scoring guidelines. 
The product of development was feasible to use because it was valid for measuring problemsolving skills of Senior High School students in the physics inquiry-based learning.

Kimberlin and Winterstein (2008) state that are constructing validity is based on accumulated scores from several studies using certain measuring instruments, and then the validity is described theoretically according to the constructed variables measured by the instrument. According to Mardapi (2012), there are five important validity proofs which are the test content-based evidence, the response process-based evidence, internal structure-based evidence, testing-consequences-based evidence, and the evidence-based on relationships with other variables. The feasibility of the instrument in terms of language must satisfy three requirements, namely employing communicative language according to the level of respondents' education, using the standardized Indonesian language, and avoiding taboo language (Matondang, 2010).

The construction test results score was 3.59 while the substance score was 3.56 , and the language score was 3.58. This means that the three aspects were very feasible. Quality criteria were based on the feasibility indicators suggested by Suyanto and Sartinem (2009) in which the indicators of feasibility aspects including construction, substance, language can be accepted if they meet the variables measured by the score of answer choices ranging from 3.26-4.00 (very feasible), 2.51-3.25 (feasible), 1.76-2.50 (less feasible), and 1.01-1.75 (not feasible). Based on these results, the performance assessment instrument to measure problemsolving skills was very feasible to use.

The instrument of performance assessment is easy to use to measure students' problemsolving skills. The indicators can serve as benchmarks for improving students' learning processes when students examine, take notes, formulate problems, express ideas, hypothesize, write results, draw graphs, analyze, and make conclusions. In the inquiry-based practicum using this instrument product, students were able to carry out a set of given tasks covering the preparation, implementation, and reporting.

The advantage of the product is that it makes it easier for teachers to assess objectively, especially on the psychomotor aspects of students listed in the instrument of performance assessment. As this product is student-centred, it helps hone the ability of problem-solving performance by analyzing through the sequence of learning scenarios. Also, it is easy for teachers to assess the contribution of each student in understanding the learning process using the provided assessment guidelines. 
The development of performance appraisal product that has been made by Almuflichan and Tjalla (2016) who develop an instrument measuring the performance of junior high school students in the physics practicum activities on vibration lessons. A comparison of development product designed by the researchers is the instrument of performance assessment that maximizes the ability of problem-solving in physics inquiry-based learning. As a result, the teachers find it easier to measure the abilities possessed by each student.

Similarly, Farisa et al. (2017) believe that problem-solving is individuals' initial awareness of certain difficulties that must be resolved at a particular time and situation. When an individual affords something, he uses his knowledge, skills, and understanding to find solutions for the unfamiliar problem/situation to improve the quality of his performance. This product also has some weaknesses regarding its implementation. Firstly, it gives more burdens for teachers in terms of efforts and time allocation. Secondly, students will experience difficulties in fulfilling all demands in the assessment. Lastly, it is less economical since the instrument is made for each student. Therefore, the more students learn in a class, the more instrument the teachers must prepare.

\section{Conclusion}

The product was tested by the four expert validators who have accepted the instrument both in terms of the content and format. The approval of this product includes the learning outline, learning scenarios, rubrics, and scoring guidelines. The development product was appropriate because it was valid. Construction, substance, and language aspects had fulfilled the feasibility with an average score of 3.59 for the construction aspect, a score of 3.56 for the substance aspect, and a score of 3.58 for the language aspect. Based on the given scores, the quality of these three aspects was very feasible. Thus, the instrument of the performance assessment can be used to measure the problem-solving skills of senior high school students in physics inquiry-based learning.

\section{Acknowledgements}

The author would like to thank Lecturers of Physics Education Department, Faculty of Teacher Training and Education, University of Lampung. 


\section{References}

Aisyah, I., \& Wasis. (2015). Penerapan model pembelajaran inkuiri untuk melatihkan kemampuan argumentasi ilmiah siswa pada materi kalor di SMA N 1 Pacet. Jurnal Inovasi Pendidikan Fisika (JIPF), 4(2), 83-87.

Almuflichan, R. M., \& Tjalla, A. (2016). Pengembangan instrumen penilaian kinerja siswa pada praktikum fisika getaran di SMP. Jurnal Evaluasi Pendidikan (JEP), 7(2), 95-106.

Amelia, F. (2015). Pengembangan instrumen asesmen kinerja praktikum pengaruh suhu terhadap laju reaksi. Jurnal Pendidikan Pembelajaran Kimia, 4(2), 543-555.

Ariani, D. (2016). Instrumen penilaian keterampilan kerja ilmiah pada pembelajaran fisika berbasis inquiry. Jurnal Penelitian Pembelajaran Fisika (JP2F), 7(2), 109-117.

BSNP. (2010). Paradigma Pendidikan Nasional Abad XXI Versi 1.0. Available Online: http://www.bsnp-indonesia.org/id/wpcontent/LaporanBSNP2010.pdf

Dewi, D. S., \& Rosana, D. (2017). Pengembangan instrumen penilaian kinerja untuk mengukur sikap ilmiah. Jurnal Kependidikan, 1(1), 67-83.

Eka, I. W. (2015). Contextual learning approach and performance assessment in mathematics learning. Journal of Indonesia Student Assessment and Evaluation (JISAE), 1(1), 28-39.

Farisa, N. F., Mardiyana, \& Kuswardi, Y. (2017). Analisis kemampuan berpikir kritis dalam pemecahan masalah matematika berdasarkan langkah-langkah facione pada materi program linear ditinjau dari minat belajar siswa kelas XI MAN Purwodadi tahun ajaran 2016/2017. Jurnal Pendidikan Matematika dan Matematika (JPMM), 1(2), 20-36.

Fraenkel, J. L., Wallen, N. E., \& Hyun, H. H. (2012). How to Design and Evaluate Research in Education Eighth Edition. New York: Mc Graw Hill.

Ihsany, Z., \& Margono, G. (2017). Pengembangan instrumen penilaian kinerja praktikum suhu dan kalor kelas X SMA. Jurnal Evaluasi Pendidikan (JEP), 8(2), 79-87.

Kimberlin, C. L., \& Winterstein, A. G. (2008). Validity and reliability of measurement instruments used in research. American Journal of Health-System Pharmacy, 65(23), 22762284.

Laksana, L., \& Dasna, I. (2017). Bagaimana melakukan penilaian proses pada pembelajaran berbasis inkuiri?. Journal of Education Technology, 1(4), 224-230.

Mardapi, D. (2012). Pengukuran Penilaian dan Evaluasi Pendidikan. Yogyakarta: Nuha Medika.

Matondang, Z. (2010). Penyusunan Instrumen/Tes Standar. Available Online: http://digilib.unimed.ac.id

Mertler, C. (2001). Designing scoring rubrics for your classroom. Practical assessment Research and Evaluation, 7(25), 1-10.

Patnani, M. (2013). Upaya meningkatkan kemampuan problem solving pada mahasiswa. Jurnal Psikogenesis, 1(2), 130-142.

Puspita, A. T., \& Jatmiko, B. (2013). Implementasi model pembelajaran inkuiri terbimbing (guided inquiry) terhadap keterampilan berpikir kritis siswa pada pembelajaran fisika materi fluida statis kelas XI di SMA Negeri 2 Sidoarjo. Jurnal Inovasi Pendidikan Fisika, 2(3), 121-125.

Putri, D. H., \& Sutarno, M. (2012). Model kegiatan laboratorium berbasis problem solving pada pembelajaran gelombang dan optik untuk meningkatkan keterampilan proses sains mahasiswa. Jurnal Exacta, 10(2), 148-155. 
Rosidin, U. (2016). Penilaian Otentik (Authentic Assessment). Yogyakarta: Media Akademi.

Rostika, \& Junita, H. (2017). Peningkatan kemampuan pemecahan masalah siswa sd dalam pembelajaran matematika dengan model diskursus multy representation (DMR). Jurnal Pendidikan Dasar, 9(1), 35-46.

Safitri, A. N., Sari, R., \& Wahyuni, S. (2017). The Influences of mathematics ability toward physics learning in senior high school based on an authentic assessment system. International Journal of Learning and Teaching, 3(1), 11-14.

Saiful. (2017). Performance assessment berbasis inkuiri terbimbing untuk membangun keterampilan argumentasi siswa. Jurnal Inovasi dan Pembelajaran Fisika, 4(2), 170-181.

Sugiyono. (2018). Metode Penelitian Pendidikan (Pendekatan Kuantitatif, Kualitatif, dan $R \& D)$. Bandung: Alfabeta.

Sulistiawan, F., Sumardi, K., \& Berman, E. T. (2017). Penerapan model pembelajaran levels of inquiry untuk meningkatkan hasil belajar siswa SMK. Journal of Mechanical Engineering Education, 4(1), 41-47.

Sundari. (2014). Model pengembangan asesmen kinerja (performance assessment) mata pelajaran IPA berbasis nilai karakter di SMP Kota Ternate Maluku Utara. Jurnal Edubio Tropika, 2(1), 168-173.

Suprananto, \& Kusaeri. (2012). Pengukuran dan Penilaian Pendidikan. Yogyakarta: Graha Ilmu.

Suyanto, E., \& Sartinem. (2009). Pengembangan contoh lembar kerja fisika siswa dengan latar penuntasan bekal awal ajar tugas studi pustaka dan keterampilan proses untuk SMA Negeri 3 Bandar Lampung. In Prosiding Seminar Nasional Pendidikan 2009. Lampung: Universitas Lampung.

Toheri \& Yeni. (2014). Perbandingan penggunaan asesmen kinerja (performance) dan asesmen penugasan terhadap kemampuan matematika siswa pada pokok bahasan garis dan sudut kelas VII MTs Negeri Cirebon II. Jurnal EduMa, 3(2), 149-162.

Uno, H. B., \& Koni, S. (2012). Assessment Pembelajaran. Jakarta: Bumi Aksara.

Uus, T. (2017). Critical thinking and problem-solving skills: how these skills are needed in educational psychology?. International Journal of Science and Research (IJSR), 6(3), 2004-2007.

Wenning, C. J. (2011). The levels of inquiry model of science teaching. Journal of Physics Teacher Education, 6(2), 9-16.

Widya \& Novianti. (2016). pengembangan rubrik asesmen keterampilan proses sains pada pembelajaran IPA SMP. Jurnal Ilmiah Pendidikan Fisika Al-BiRuNi, 5(1), 131-140.

Yeni, S. (2017). Pembelajaran berbasis praktikum sebagai sarana siswa untuk berlatih menerapkan keterampilan proses sains dalam materi biologi. Jurnal Bio Educatio, 2(2), 4957.

Yusi, A. (2016). Berpikir kritis siswa dalam pembelajaran berbasis masalah berbantuan kunci determinasi. Jurnal Pendidikan Indonesia, 5(2), 901-911. 